\title{
Growth Strategies in Foreign-Invested Enterprises through Stabilizing Industrial Relations: A Case Study on Oriental Brewery ${ }^{*}$
}

\author{
CHANGMIN LEE $^{* *} \cdot$ HyOUNG-GoO KANG ${ }^{* * *}$ \\ AND YOUNG-SANG YI ${ }^{* * * *}$
}

\begin{abstract}
This paper suggests ways to develop healthy industrial relations at foreign-invested enterprises after M\&A by studying Oriental Brewery Co., Ltd ("OBC") case. OBC has the unique feature of being a foreign private-equity-fund (KKRKohlberg Kravis Roberts) invested company with dual unions. It is the only consumer product company in Korea that has regained the number one position in 2011 after 15 years of a continuous drop from the once dominant position with up to $70 \%$ of market share in the early 1990 s. We have identified the contributing factors of such success from the perspective of union-management relationship before and after the M\&A.
\end{abstract}

Keywords: Mergers and Acquisitions, Industrial Relations, Multiple Unions, Labor-Union Risk, OB, Oriental Brewery, Breweries, Organizational Culture, Foreign Direct Investment, Korea

* This work was supported by the National Research Foundation of Korea Grant funded by the Korean Government(NRF-2013S1A5A8021046).

** Assistant Professor, Hanyang University; E-mail: changmin0415@gmail.com

*** Assistant Professor, Hanyang University; E-mail: hyoungkang@gmail.com

${ }^{* * * *}$ Ph.D. Candidate, Hanyang University; E-mail: bryan_yi@naver.com 


\section{INTRODUCTION}

Marking the financial crises as turning points, the foreign direct investment onto Korean enterprises has shown a major shift. Korea has seen a rapidly growing amount of foreign investment after it has started to encourage businesses to take more foreign investment, in order to fight possible economic crises. The country has opened the economy to foreign investors in the areas including finances, mergers and acquisitions, real estates and related regulations, and it has enacted the related laws to draw more foreign funds. Moreover, to attract more foreign investors, "Invest Korea" (former name "Korea Investment Service Center") opened up in Korea in 1998 to provide investment information. As the amount of foreign investment that each nation receives indicates global competitiveness, such investments carry a huge significance. Foreign investment has become an important part of the economy, as the world has become globalized and the overseas investment has been active more than ever.

However, one cannot deny that Korea's industrial relations have been one of the factors that have kept foreign investors away from eyeing on local companies. Although Korea was ranked the top $22^{\text {nd }}$ nation for high competitiveness across the world, the statistics from the International Institute for Management Development (IMD) in 2012 show that the productivity induced from industrial relations has put Korea in the $53^{\text {rd }}$ place among 59 countries. In 2011, Korea has ranked 140 among 142 countries according to the World Economic Forum (WEF), as it saw little cooperation between management and labor, required to keep companies competitive. Another statistic released by the World Bank shows that Korea has been ranked 150 among 183 nations for having one of the worst employment markets, which indicates high rigidity of employment.

One of the reasons for such characteristics of the labor-management relations in Korea is due to Korea specific employment relations and to the tradition stemming from its historical and cultural background. There might be the risk of a deterministic approach if we interpret the labor-management relations of a country only within the framework of the national institution, the economic structure and the political factors based on historical and cultural background. However, it could be a meaningful starting point for understanding the differences among the countries.

In the case of the UK, labor-management relations have shown mature and self-governing features in that the union and the management respect the basic rights and responsibilities of the counterparties (Bamber and Lansbury 2000, 3870). In France, the union is viewed to be predisposed to politics with the belief that management is inherently different from labor and that class struggle is the basis of the union (Bamber and Lansbury 190-224).

In Germany, labor-management relations are more democratic in that work- 
ing conditions are decided by agreement, keeping the promise based on the good faith between unions and management (Bamber and Lansbury 225-248).

In the case of Japan, it contains paternalistic features stemming from the tradition of the zaibatsu after the Restoration of Meiji. This formed a tacit promise of lifetime employment with a wage system based on years of service. The unions in Japan have been maintaining a solid inter-dependency between unions and management based on the strong bond driven from the sense of a common destiny, with the company union as dominant, holding company-centered activities by the cooperative unions, including employee participation in the management decision process, promoting union leaders to management positions, and holding qualityenhancement activities (Bamber and Lansbury 278-306).

In Korea, the government had chosen the chaebeol (conglomerate) as a major tool for industrialization and the unions had been forced by the national government to accept the arrangement. However, as the legitimacy of the authoritarian governments has been challenged along with the successful industrialization, the right of the laborers and of the union has become part of the agenda for the reform under such nationwide democratization. In the newly industrialized Asian countries such as Taiwan, Hong Kong, Singapore and Korea, labor union movements have been subordinate to government-driven economic development; and Korea was no exception. With such historic background, the unions in Korea have pursued the freedom of association, and have yearned for the equal footing with chaebeol, hence displaying political features (Bamber and Lansbury 307-326, Shin, Kim and Lee 2012, Chapter 2).

On top of the historical and cultural background mentioned above, the reasons for the dismal reality of labor-management relations in Korea expressed with such rankings are mentioned as follows.

The unfavorable industrial relations often come from labor unions, especially the full-time employees at conglomerates, taking strong actions. Due to repeating strikes, labor unions' one-sided attack is considered the major factor that weakens the amicable relationship between the management and labor. As a natural reaction, management also does not want to approach the union since the trust and predicttability level has become too low. In fact, many foreign investors or potential investors seem to view the local labor unions to be too hostile on political issues that are irrelevant to their working conditions. This vicious cycle has prevented Korea's industrial relations from maturing and growing healthy as management often rejects dealing with the violent labor unions.

In this paper, we discuss ways to create cooperation between management and labor, while restricting strikes so that the companies can focus on fostering their growth momentum. OBC, since its establishment in 1933 until 1998, kept the management system not so different from other typical Korean companies. The company has had a labor union chapter affiliated with the Federal of Korean Trade 
Unions. After it experienced three mergers and acquisitions, the company ended up having some unique features, including foreign shareholders and dual labor unions. The company has been bought out by a foreign shareholder, Interbrew, in 1998, and has acquired Cass Beer (which triggered the formation of another union affiliated with the Korean Confederation of Trade Unions). Later in 1999, 100\% of OBC's shares were bought out in 2009 by Kohlberg Kravis Roberts or "KKR.", KKR immediately sold half of OBC's take to Affinity Equity Partners, ${ }^{2}$ allegedly for taking advantage of Affinity's experience from 'a number of lucrative exits in Korean companies in recent years' on top of predictable purpose of 'spreading the financial burden and pooling their skills and networks' (Financial Times, July 7, 2009). This M\&A is a case in which financial investors (FI) had purchased the shares of the second largest brewer in Korea with a view to selling the shares at a much higher value in future to either other FIs or strategic investors (SI) such as LotteChilsung.

By studying this OBC case, we search for more "refined" ways to develop healthy industrial relations at foreign-invested enterprises, and to improve companies' performance after M\&As. First of all, it is necessary for management to build up a partnership with a labor union. Labor unions need to come up with feasible labor campaigns, and management needs to build trust and lead the company more effectively. Second, management needs to focus on raising productivity by deciding promotions and salary raises based on objective criteria and rational decisions. Additionally, the company should establish industrial relations that can push for higher productivity rather than for simple redistribution. Third, both on-site managers and supporting teams need to take the responsibility for the management of labor, and share the information with their subordinates to resolve any rising issues. The union and the management need to build trust through communicating frequently, by holding conferences, or official and unofficial meetings in order to make it work. Fourth, in order to prevent the union from making excessive requests, the company should inform the employees of the overall progress and the status through internal communication. Fifth, management needs to set and abide by consistent rules and principles, so that the employees or the labor union can rely on them. Finally, management should maintain a variety of communication channels and try to have employees strengthen loyalty towards the company. The company should be open to listening to complaints, opinions, and hardships as frequently as possible.

As the methods for this case study, the authors referred to scholarly papers, on-site observations, interviews with relevant $\mathrm{OBC}$ management and employees.

\section{LITERATURE REVIEW}

Our paper focuses on stabilizing labor-management relations in the context 
of HRM after M\&A. Although there are many studies on post-merger management from the organizational culture and the human resource perspective, there are few papers on the relationship between labor-management relations and the company's overall performance. Nahavandi and Malekzadeh (1988) propose that the degree of congruence between the acquirer and the acquired organizations' preferred model of acculturation will affect the level of the acculturative stress. And they show that the acculturative stress, in turn, facilitates or hinders the implementation of a merger. Sheridan (1992), from analyzing the retention rates of 904 college graduates, who have been hired in six accounting firms over the six-year period, have found that the cultural effects are stronger than the combined exogenous influences of the labor market. The results indicate that interpersonal relationships and respect for people explain most of the variances across the firms. Cartwright and Cooper (1993) have examined the role of cultural compatibility in determining venture outcomes, and they suggest that a culture "audit" of a potential, or of a recently acquired organization, is a valuable source of information, with implications not only for partner selection but also for long-term management. Weber Shenkar and Raveh (1996) make a distinction in the concept of the cultural fit by examining both international and domestic mergers. They find that in the international M\&A, differences in the corporate culture have a positive effect on the post-merger period - contrary to domestic M\&As.

Larsson and Finkelstein (1999) have tried an integrated M\&A model comprising the perspectives of strategic management, economics, finance, and organization. Although not mutually exclusive, those perspectives are only marginally informed by one another. Larsson and Finkelstein suggested that the success of a merger and acquisition is influenced by the degree of synergy realization, rather than by potentially ambiguous criteria such as accounting or market returns. With a view to enhancing the success of mergers and acquisitions, by focusing on organizational culture, Schraeder and Self (2003) offer a comprehensive perspective to suggest a check list of nine strategies before and after the event. Riad (2005) theorizes that 'organizational culture' as a discursive formation in merger integration is implicated in a regime of truth. Lastly, Kavanagh and Ashkanasy (2006) have examined the mergers between three large multi-site public sector organizations, and they find that the leaders, the pace of change and communication, and the transparent change process are all important.

\section{THEORIES ON STRIKES}

The economic theory behind the strike states that the issues up for negotiation involve not only salaries and the working conditions but also other institutional tools that relate to the stability of labor unions when making a collective agreement. Although matters that come up on the negotiating table vary depending 
on the market, the requests from the labor union mainly involve labor costs. Therefore, the essence of collective bargaining is to decide upon the labor cost. Strategically speaking, the union usually asks for options that the management cannot fully accept at the negotiating table. Both management and labor union would then try to have the other surrender. The most important strategies in negotiations are to decide the amount of money acceptable to both the union and the company, the amount of money the company can give, and the period of fighting the company can stand. Many political theorists studying labor disputes see them as natural power struggles. They consider that a country's general sentiment over industrial relations is established after a series of fights to win power and social status (Kim and Yoon 1991, 71-79).

By considering the various approaches mentioned above, Godard (1992) and Gramm (1986) and more recently, Campolieti et al (2005) have conducted analyses with detailed data. They criticize the study on labor strikes from the neo-classical economics perspective for over-simplifying and/or for reaching wrong conclusions by using administrative statistics and industrial variable statistics. They believe that the variables at the micro-unit level are crucial. Godard tries behaveoral analysis while claiming to utilize the research performances from the areas of structural economics and industrial sociology. He views the strike as a strategy which not only brings economic benefits but also confirms and utilizes the sociopolitical power through making a group voice representing complaints of union members (Cho 2004, 44-45).

TABLE 1. SUMMARY OF THEORIES ON LABOR STRIKE

\begin{tabular}{|c|c|c|}
\hline Category & Theory & Major contents \\
\hline \multirow{4}{*}{$\begin{array}{l}\text { Economic } \\
\text { theory }\end{array}$} & Hicks (1946)’ model & $\begin{array}{l}\text { Whether to go on strike and for how long the } \\
\text { strike continues will be decided based on the } \\
\text { action taken by the management and the level } \\
\text { of aggressiveness of the labor union }\end{array}$ \\
\hline & $\begin{array}{l}\text { Strikes broke out due to } \\
\text { political reasons: Ashenfelter } \\
\text { and Johnson (1969) }\end{array}$ & $\begin{array}{l}\text { Political conflicts between the management } \\
\text { that wants to maximize the profit, and the } \\
\text { labor union that wants to gain trust from the } \\
\text { employees }\end{array}$ \\
\hline & $\begin{array}{l}\text { Total Cost: Reder and } \\
\text { Neumann }(1980)\end{array}$ & $\begin{array}{l}\text { Degree of strikes is in inverse proportion to } \\
\text { damages on both management and labor union }\end{array}$ \\
\hline & $\begin{array}{l}\text { Asymmetric Information: } \\
\text { Kennan (1986) }\end{array}$ & $\begin{array}{l}\text { Strategic moves to find out the hidden motif } \\
\text { of the counterpart }\end{array}$ \\
\hline Political theory & $\begin{array}{l}\text { Theories in the arena of } \\
\text { political science: Shorter and } \\
\text { Tilly (1974), Korpi and } \\
\text { Shalev (1979), Hibbs (1976) }\end{array}$ & $\begin{array}{l}\text { Variables influence labor disputes as industrial } \\
\text { relations in a country are an aftermath of } \\
\text { social status, power structure, and politics and } \\
\text { economy }\end{array}$ \\
\hline
\end{tabular}

SOURCE: Kim Tae-gi, Yoon Bong-jun. 1991. Studies on labor disputes. Korea Labor Institute 71-79. 
In result, disputes regarding industrial relations are intertwined with economic, political and behavioral factors, rather than with just one theoretical background. The causes for labor disputes come from more complicated factors: fights for higher salaries and better welfare programs with collective bargaining, discomfort from the psychological conflicts at the negotiating table, troubles from structural hierarchy, arguments about having laid-off workers return to work, securing facilities for the union, and requests to make revisions on legal clauses.

\section{THE STATUS OF FOREIGN-INVESTED COMPANIES IN KOREA}

\section{The Status of Labor Disputes of the Foreign-invested Companies}

Labor disputes within foreign-invested enterprises are characterized by several unique features: (i) There are more disputes arising from the company's Korea Confederation of Trade Union chapter than from the Federation of Korea Trade Unions chapter; (ii) more disputes arise from a business where at least one dispute case has risen before; (iii) more disputes arise from the sites whose CEO or plant manager is a foreigner than from the sites that has leadership under a Korean CEO or manager; (iv) more dispute cases are found in the manufacturing industry, especially for auto parts or steel makers. And those disputes usually arise between May and August every year, similar to what have been seen at other Korean companies as well.

TABLE 2. Statistics On LABOR Disputes AT ForEIGN-INVESTED ENTERPRISES

(Unit: No. of cases, \%)

\begin{tabular}{lccccccccc}
\hline \multicolumn{1}{c}{ Category } & 1999 & 2000 & 2001 & 2002 & 2003 & 2004 & 2005 & 2006 & 2007 \\
\hline $\begin{array}{l}\text { Total No. of dispute } \\
\text { cases (A) }\end{array}$ & 198 & 250 & 235 & 322 & 320 & 462 & 181 & 138 & 115 \\
\hline $\begin{array}{l}\text { No. of dispute cases } \\
\text { at foreign-invested } \\
\text { enterprises (B) }\end{array}$ & 9 & 31 & 20 & 26 & 32 & 34 & 5 & 14 & 14 \\
\hline Ratio (B/A) & $4.5 \%$ & $12.4 \%$ & $8.5 \%$ & $8.1 \%$ & $10 \%$ & $7.4 \%$ & $2.7 \%$ & $10.1 \%$ & $12.1 \%$ \\
\hline
\end{tabular}

SOURCE: Ministry of Employment and Labor. 2008. Analysis of labor disputes and related statistics. Labor ministry's industrial relations countermeasure team.

There are several reasons for such labor-management conflicts in foreigninvested companies. First, the possibility of a business transfer could create an imbalance in the negotiation dynamics. The threat of moving the business overseas mostly weakens the union's negotiation power and strengthens that of the management. In case of a strike, the existence of an alternative supply option from overseas plants does not help maintain the trust level between the union and the 
management. Second, the degree of centralization at the global headquarters for decision making matters. Delayed decision making and geometric distance can contribute to the procrastinated agreement and extended strikes. Third, the difference in the socio-cultural background and the value system appears to play an important role in the conflicts.

\section{TABle 3. A Quick ReView of CASES of Stabilized LabOR RELATIONS AT ForeigN- INVESTED ENTERPRISES}

\begin{tabular}{|c|c|}
\hline $\begin{array}{l}\text { Name of } \\
\text { company }\end{array}$ & Contents \\
\hline $\begin{array}{l}\text { Renault } \\
\text { Samsung } \\
\text { Motors }\end{array}$ & $\begin{array}{l}\text { - Establish a task force team for both labor and management. Discuss troubles to } \\
\text { draw an agreement. Renegotiate on the settled issues when changes come up. } \\
\text { - Share key business information and the market trend with representatives of the } \\
\text { employees (Representatives join the business strategy meetings. CEO gives out } \\
\text { presentations for all employees three times a week on the company's operation). }\end{array}$ \\
\hline $\begin{array}{l}\text { Alps } \\
\text { Electric } \\
\text { Korea }\end{array}$ & $\begin{array}{l}\text { - Dispatch former labor union members to company's key division so that they can } \\
\text { adopt another view to look at disputes. } \\
\text { - Show how transparent the management record is. (The management report to the } \\
\text { entire employees every month } \\
\text { - Deliver any complaint discussed in a monthly team meeting to the management. }\end{array}$ \\
\hline $\begin{array}{l}\text { DHL } \\
\text { Korea }\end{array}$ & $\begin{array}{l}\text { - Hold a monthly briefing to each team (President and executives notify the } \\
\text { company's business decisions to employees face to face) } \\
\text { - All executives including the president visit regional offices all across the country } \\
\text { and hold business presentations }\end{array}$ \\
\hline $3 \mathrm{M}$ & $\begin{array}{l}\text { - No discrimination between office workers and production workers//No salary } \\
\text { difference between the professionals and administrators when promoted } \\
\text { - Offer a chance to go on a overseas training for six days or less when each team or } \\
\text { division reaches target performance } \\
\text { - Operate a overseas training for three days for the teams who didn't match the } \\
\text { target performance to provide some encouragement }\end{array}$ \\
\hline $\begin{array}{l}\text { Fuji } \\
\text { Xerox } \\
\text { Korea }\end{array}$ & $\begin{array}{l}\text { - Release video of president who explains details on decision making process for } \\
\text { the company } \\
\text { - All employees can communicate with executive members through email or posts } \\
\text { on the online boards } \\
\text { - President join labor union meetings to explain the business trend, and to listen to } \\
\text { what labor union has to say } \\
\text { - Invite employees and the management to discussion forums. President visit } \\
\text { regional offices to hear the complaints and to hold presentation on the operation }\end{array}$ \\
\hline $\begin{array}{l}\text { Stats } \\
\text { ChipPac } \\
\text { Korea }\end{array}$ & $\begin{array}{l}\text { - Operate three-step negotiation process (Discussion among on-site managers and } \\
\text { labor union members } \rightarrow \text { discussion among company's management at head- } \\
\text { quarters and labor union executives } \rightarrow \text { quarterly discussion among the labor } \\
\text { and the management) } \\
\text { - President, head of labor union, and on-site workers have conferences over a meal }\end{array}$ \\
\hline
\end{tabular}

SOURCE: Ministry of Employment and Labor. Labor ministry's industrial relations cooperation policy division. 2008. Yes Korea! Reports on successful establishment of industrial relations at Korea's foreign-invested enterprises in 2008.

\section{Characteristics Found in Foreign-Invested Companies}

The basic conditional difference in the labor-management relations of foreign 
invested companies, especially owned by multi-national corporations, is that the union is the company-specific and country-specific whereas the corporations have a global orientation. Therefore, it seems necessary to pay more attention to factors that affect labor-management relations, such as business practices in the head quarter country, the motivation of investment into the country, the type of investment ( $\mathrm{JV}$, partially owned or wholly owned), the business practices of the invested country, the characteristics of the labor union activities, and the differences in the institution and culture (Noh and Kim 2003, 33-36).

(1) In the early times, when foreign investors started to focus on local enterprises, there was a high chance of occurrence of conflicts among labor unions and foreign CEOs because the former is more accustomed to making business decisions based on the heart, while the latter centers on making the most rational decisions.

(2) It is important to establish communication tools between foreign management and the Korean workers, despite their cultural differences of work ethic, attitude, lifestyle, and communication style.

(3) There is a possibility that labor unions ask to take part in business management, and request guaranteed employment or incentive payment based on the short-term performance, since their main concern is always job security, in case foreign-invested companies stop investing into the local company.

(4) There is a chance of conflict when the management hastily applies a foreign work system, since the employees and the labor union may reject it. The employees may feel that they could get a salary cut or could lose their jobs with a foreign system.

(5) Foreign-invested enterprises try to follow the local law, when establishing a new policy or making a business decision. Hence, when a strike breaks out, they tend to strictly apply the "no labor, no payment" rule or shut down the work sites.

\section{STRATEGIES TO STABILIZE LABOR RELATIONS: THE OBC CASE}

\section{First-Step Strategies with a View to Stabilizing Labor-Management Relations at $O B C$}

OBC has maintained relatively stable employment relations since its establishment in 1933. The company's labor union chapter, under the Federation of Korea Trade Union, was established on May 31, 1953. The first ever strike at the company occurred on June 29, 1987, as the labor union requested higher salaries and better working conditions, whilst the management was unwilling to accept the requests. The one-week-long strike made the management realize the importance of keeping good industrial relations for its smooth business operation. Since then, the management has started paying special attention to the complaints raised by its 
employees.

OBC started to lose the market share in 1993, and it let Crown Beer (currently Hite-Jinro) take over more than 50 percent of the market share by 1996. To win back its market share, it has established a joint venture with Belgium-based Interbrew (now Anheuser-Bush InBev) in 1998, and then it acquired Cass brand from the bankrupt Jinro in 1999. Since then there are virtually only two beer manufacturers in Korea. Cass labor union was established during the acquisition process, and it signed up to be a chapter of the Korea Confederation of Trade Unions.

Therefore, OBC had more than one labor union about a decade before having multiple labor unions in a company was legalized in July 2011 (The local labor ministry allowed multiple labor unions for one company when such cases arise from the buying and selling of a business).

Cass labor union went on strike for 16 days, asking for 16 specific requests including the guarantee of job security. During this long strike, both the management and the labor union witnessed damages without reaching any solution. This pushed the company's market share to go down further.

The labor union held a two-day fight during a wage bargain in 2003, and another 14-day-long strike to decide whether to adopt a new system of working 40 hours per week in 2004. Due to these strikes, followed by the already falling sales, the company's market share went further down. In 2006, the company experienced its lowest-ever market share of 38.7 percent.

Around 2004, as the industrial labor union chapters of Korea Confederation of Trade Unions became widespread, Korea suffered from severe labor disputes. Furthermore, when the leader of the industrial labor union at $\mathrm{OBC}$ was elected as the head of Chemicals and Fibers Industrial Union under the Korean Confederation of Trade Unions, the company's work sites were targeted for political attacks.

The Industrial labor union assumed a hostile stance to overcome conflicts with the management in an attempt to set exemplary cases for other chapters. As more employees developed fears of losing their jobs at foreign-invested enterprises, the industrial labor unions gained even more support. It seems that the labor union did not care much about economic rationality. At the same time, the management of OBC, many of them being foreigners, were defensive and unappreciative of such hostile union movements. However, such reactions only exacerbated the situation. In 2009, KKR - an American private equity fund - acquired OBC from InBev. During this process, the Federation of Korea Trade Unions and the Korean Confederation of Trade Unions gained more power, and the two fought against the management and the shareholders. Afterwards, the two labor unions solidified further and the first joint collective bargaining came into the scene in 2010 . 
TABLE 4. A SHORT CHRONOLOGY OF OBC'S RELATED TO M\&AS AND LABOR DISPUTES

\begin{tabular}{cll}
\hline Year & \multicolumn{1}{c}{ Month } & \multicolumn{1}{c}{ Contents } \\
\hline 1933 & December & Established Sohwa Girin Beer Company \\
\hline 1948 & February & $\begin{array}{l}\text { Company name changed to Dongyang Beer Company, product name } \\
\text { changed to OB Beer }\end{array}$ \\
\hline 1952 & May & Official launch of Dongyang Beer Company \\
\hline 1995 & March & Company name changed to OBC \\
\hline 1998 & June & Merger with eight Doosan Group subsidiaries \\
\hline 1998 & September & Established a joint venture with Belgium-based Interbrew \\
\hline 1999 & December & Acquired CASS Beer Company \\
\hline 2000 & & 15-day strike (Regarding M\&A) \\
\hline 2003 & & Two-day strike (Salary bargaining) \\
\hline 2004 & & 14-day strike (Collective bargaining) \\
\cline { 1 - 1 } 2009 & July & Kohlberg Kravis and Roberts became the shareholder \\
\cline { 1 - 1 } 2009 & & Three-day strike (Regarding M\&A) \\
\cline { 1 - 1 } 2011 & & One-day strike (Salary bargaining, Veto to weekend works) \\
\hline
\end{tabular}

SOURCE: Oriental Brewery.

\section{TABle 5. Profiles OF TWO UNIONS IN OBC}

\begin{tabular}{|c|c|c|}
\hline Category & Incheon labor union & Cheongwon labor union \\
\hline Name & $\begin{array}{l}\text { OBC Labor Union, Federation of } \\
\text { Korean Chemical Worker's Union }\end{array}$ & $\begin{array}{l}\text { Chapter at OBC, Federation of } \\
\text { Chemical and Fiber Industry }\end{array}$ \\
\hline Establishment & May 31,1953 & July 17,1999 \\
\hline $\begin{array}{l}\text { Superior } \\
\text { organization }\end{array}$ & $\begin{array}{l}\text { Federation of Korean Chemical } \\
\text { Worker's Union, Federation of } \\
\text { Korean Trade Unions }\end{array}$ & $\begin{array}{l}\text { Federation of chemical and fiber labor } \\
\text { union, Korean Confederation of Trade } \\
\text { Unions }\end{array}$ \\
\hline Membership type & Open shop & Open shop \\
\hline No. of predecessor & $\begin{array}{l}5 \text { (including one dispatched to } \\
\text { superior organization) }\end{array}$ & 4 \\
\hline $\begin{array}{l}\text { No. of union } \\
\text { members }\end{array}$ & 448 (98 percent of the labor joined) & 947 (89.2 percent of the labor joined) \\
\hline Structure & $\begin{array}{l}1 \text { headquarters and } 2 \text { offices (factory } \\
\text { in Icheon and Gwangju) }\end{array}$ & 1 headquarters and 1 office \\
\hline Election & September 2012 & October 2013 \\
\hline $\begin{array}{l}\text { Disposition of labor } \\
\text { union }\end{array}$ & $\begin{array}{l}\text { Moderate/ Open to discussion and } \\
\text { cooperation/ Lenient and pursue } \\
\text { practicality for both the labor union } \\
\text { and the management }\end{array}$ & $\begin{array}{l}\text { Stiff/ Carry fights along with } \\
\text { conversations/Put a priority on labor } \\
\text { union and political revision }\end{array}$ \\
\hline Strike history & $\begin{array}{l}\text { For a week in } 1987 \\
\text { Three days in } 2009 \text { (Regarding } \\
\text { M\&A) } \\
\text { One day in } 2011 \text { (Rejected to work } \\
\text { on weekends) }\end{array}$ & $\begin{array}{l}15 \text { days in } 2000 \text { (Regarding M\&A) } \\
\text { Two days in } 2001 \text { (Salary bargaining) } \\
14 \text { days in } 2004 \text { (Collective bargaining) } \\
\text { Three days in } 2009 \text { (Regarding M\&A) } \\
\text { One day in } 2011 \text { (Rejected to work on } \\
\text { weekends) }\end{array}$ \\
\hline $\begin{array}{l}\text { Dispatch of } \\
\text { predecessor }\end{array}$ & $\begin{array}{l}\text { Federation of Korean Chemical } \\
\text { Worker's Union, Gyeonggi chapter }\end{array}$ & $\begin{array}{l}\text { Former representative of Federation of } \\
\text { chemicals and fibers, Korean } \\
\text { Confederation of Trade Unions } \\
\text { Former deputy representative of } \\
\text { Korean Confederation of Trade Unions }\end{array}$ \\
\hline
\end{tabular}

SOURCE: Oriental Brewery. 
OBC, which used to have a dominant position of more than 70 percent of the market share until the early 1990s, saw its presence shrinking down to 38.7 percent in 2006. However, after the new management took over in 2007, the company's market share started to bottom out. It climbed to over 50 percent in 2011, and it continued to go higher in 2012 to 55 percent. Net sales for six years, from 2006 to 2012, have grown by 2.1 times (13.5 percent compounding annual growth rate for 6 years). Net income has also jumped to 266 billion won in 2012 from 51 billion won in 2006, 4.2 times! The company's sales, marketing, production, finance, and industrial relations have all created a synergy effect for a remarkable performance.

TABLE 6. INCOME STATEMENT OF OBC, FY2006 VS. FY2012

\begin{tabular}{llll}
\hline \multirow{2}{*}{ (KRW Million) } & \multicolumn{3}{c}{ Audited Income Statement } \\
\cline { 2 - 4 } & $2006 \mathrm{FY}$ & $2012 \mathrm{FY}$ & 2012 vs $2006 \%$ \\
\hline NNT & 587,858 & $1,259,711$ & $114.3 \%$ \\
\hline Gross Turnover & $1,152,344$ & $2,266,554$ & $96.7 \%$ \\
\hline Excise taxes & $(564,487)$ & $(1,006,843)$ & $(78.4 \%)$ \\
\hline COGS & 261,777 & 530,816 & $102.8 \%$ \\
\hline Gross profit & 326,081 & 728,895 & $123.5 \%$ \\
\hline SG\&A & 246,651 & 360,921 & $46.3 \%$ \\
\hline Operating profit & 79,430 & 367,974 & $363.3 \%$ \\
\hline Other income & 8,967 & 5,894 & $34.3 \%$ \\
\hline Other expenses & 5,603 & 9,079 & $62.0 \%$ \\
\hline Financial income & 13,894 & 9,954 & $28.4 \%$ \\
\hline Financial expenses & 13,533 & 26,167 & $93.4 \%$ \\
\hline EBT & 83,155 & 348,576 & $319.2 \%$ \\
\hline Corporate income tax & 32,220 & 82,530 & $156.1 \%$ \\
\hline Net profit & 50,935 & 266,046 & $422.3 \%$ \\
\hline
\end{tabular}

SOURCE: DART, Financial Supervisory Service.

In this paper, we focus on how reforms in human resource management have contributed to the company's growth. To the management, one of the largest risks to be controlled is the labor union's strike, especially during the high season. In fact, the company experienced a lowering market share during the 16-day-strike in 2004, which occurred prior to the busy season of the year. The management then realized the importance of industrial relations and set up a five-year master plan to reform industrial relations in December 2007. As the management executed the plan in a consistent way and used it as a foundation for further growth, it has managed to keep stability even after the M\&A in 2009. The strategies for stabilizing labor-management relations are as follows: 


\section{(1) Industrial Relations Management}

\section{(i) The Paradigm Shift: "Union, another partner."}

Since the new management took over in 2007, the management started making an effort to understand its labor union and employee perception better. The company first needed to understand why employees were seeking protection from the labor union, not from the management. It was mainly because the employees experienced two M\&As due to the difficulties the company had experienced before. To prevent such a situation from amplifying doubts among employees due to a lack of information, the management has put more effort to provide as much information to the employees. The company now shares its performance and other major issues with the labor unions twice a year, and with employees through "Monthly Communication Meetings" and frequent town-tall meetings.

Such a move helped the employees not only have better understanding of the company's performance, but also have motivation to achieve the performance target. At the same time, the unions also appreciated the change in the stance of the management and began to express what they really wanted.

\section{(ii) Job Security: The Management kept the Promise}

Although the company has started to recover its market share since 2007, it still has had to focus on reconstruction until 2009. One of the hottest issues that has come up every year has been whether to decide on keeping or shutting down the plant in Gwangju, which had been showing financially unacceptable operational rate due to the slowdown of sales. However, the management did not succumb to the request of the shareholder to close it at the time. The management was fully aware of the inefficient production level. However, the company convinced the shareholder to keep it by expanding exports to raise operational rate of Gwangju plant. After the management made a tough decision to revive the plant, the employees working in Gwangju showed more loyalty to the company. The company's sales performance improved, and the Gwangju plant currently serves as an indispensible base for both exports and domestic sales. Even after the KKR buyout in 2009, the same management team continued to operate OBC without any visible form of reconstruction. Yet the management fortified the compensation system based on meritocracy and highly rational management, instead of reforming the internal policies that usually results in salary cuts or degraded working conditions.

\section{(iii) Principle-Centered Management: Abiding by Laws and Rules}

In the past, the management often compromised with its principles when the labor union threatened the company with potential strike action. The labor union has attempted to interfere with human resource management, has requested unrealistic and expansive interpretation of the definition of "legitimate labor union 
activities", and/or an irrational salary rise. Therefore, the trust between labor and management was broken, and the interaction between the two decreased. To change the dynamics, the management decided to take a firm stance and stick to the principles by clearly explaining why only certain things could be granted to the labor union. Although the management went through a lot of difficulties in the early stage, the labor union started to be more prudent and stopped making frivolous requests by realizing the risk of the boomerang effect. Eventually, the unnecessary labor disputes have started to clear out in the scene.

\section{(iv) "At-all-times" Communication between the Union and the Management}

Once the annual wage negotiation or the biennial collective bargaining agreement was completed, the communication window for other discussions between labor and management was closed most of the time. Since 2010, OBC has established a committee co-operated by the labor and the management so that the two parties can continue to interact even after the collective bargaining agreement of the salary increase rate agreement. At the committee, the management and the labor have discussed matters, which need to be further discussed at the next CBA to keep the session short, since prolonged collective bargaining puts a delay on company's business operation. Also, the quarterly meetings between labor and management opened after collecting opinions and complaints through small group sessions. Moreover, a safety and hygiene committee has been established by both the labor and the management in 2004. In an effort to enhance the safety and the health of employees, the committee meets every February.

\section{(v) The Labor-Management Workshop: Understanding Counterparties}

The management and the labor union have held an annual workshop every October since 2010, in order to share each other's value and to understand the counterparty better. The gap has still existed despite the pursuit of their common goal: the growth and improvement of working conditions. They have yet shown a big difference in measures and time period to achieve the goal. However, many issues have seemed to resolve faster than before, as both sides have understood the counterparty better.

\section{(vi) Collective Bargaining Agreements before Peak Season: Timing Management}

$\mathrm{OBC}$ has three plants, more than 35 sales branches, and 24 distribution centers across the nation, and it is very important for those functions to properly deal with the high demand during the peak season. During the peak season that lasts from May to August, the company sees around 50 percent of its early sales. The plant is extremely vulnerable to even partial strikes, since the manufacturing process in both brewing/production and packaging are in a linear production and a conveyer-based packing system by its nature. 
Because the management has already fully recognized the burden from the previous strikes during the peak season, it has focused on changing the process of collective bargaining. Gradually, the collective bargaining agreement has been a faster process since 2010. Collective bargaining, which usually lasts until the heart of the peak season around July through August, ended early in April of 2012.

\section{(vii) Issues Involving Multiple Unions}

OBC has had two labor unions, the Cheongwon Labor Union (mostly covering the employees in sales, headquarters and the Cheongwon Plant) and the Icheon Labor Union (mostly covering the employees in Icheon and Gwangju plants), a decade before it was legalized for a company to have multiple unions. As mentioned before, the leader of the Cheongwon Labor Union has become the first leader of the Chemicals and Fibers Industrial Labor Union under the Korea Confederation of Trade Unions, and it has formed a foundation for the introduction of the industrial unions in Korea. The hostile Cheongwon Labor Union and the rather moderate, but not-so-friendly, Icheon Labor Union, have shown differrences in many respects including the operation of each union, and the ways to participate in collective bargaining. OBC could not avoid the complicated industrial relations, which appears to be a microcosm of all types of industrial relations in Korea.

The management recognized that each union has unique interests and needs, warranting different solutions. Therefore, the management carefully conducted the collective bargaining to respect employees in all areas including sales, production, and the headquarters, and it has used various communication tools to talk to different groups, installing a balanced communication process so that no group felt ignored.

\section{(viii) Prioritization of Agenda regarding the Industrial Union}

Cheongwon Labor Union leads not only the company union, but also the Chemicals and Fibers Industrial Union at the same time, and represents North Chungcheong Headquarters for the Korea Confederation of Trade Unions. Hence, the union needs to follow the directions from these two upper organizations on top of handling the company specific issues. Labor and management have been wasting their time and effort as the labor union has been dealing with many other issues irrelevant to the company's operation.

Therefore, $\mathrm{OBC}$ constructed several rules to prioritize agendas, in an effort to encourage the unions to discuss the problems relevant to the company. When necessary, the management talked to the labor unions first in order to inform them better, so that it would help the two unions to come up with tangible solutions during the collective bargaining sessions. As a result, the employees started to see better working conditions and welfare programs. 


\section{(ix) Proactive Communication to Employees on the Ongoing Issues}

Many disputes between labor and management involve issues of working conditions and welfare programs. In the past, companies have not directly communicated with employees in regards to such issues. The management used to deliver the message unilaterally to avoid provoking the labor unions. It has been a typical modus operandi of the union that has raised and highlighted issues, has shown confrontational process, and has resolved them with the management. Such a process has often created misunderstanding, as employees expected more in the end than what the company could afford. To prevent any of the previous problems from happening, the management decided to communicate more actively with the employees. Having been given more direct and active communication channels within the company, the employees were able to understand the company's actions, and have developed more trust for management. As a result, such active communication has helped the employees reach their expectations, although there was some negative reaction from the labor union at the initial stage. With a view to facilitating such progress, the company has executed a series of leadership programs through a variety of workshops and regular teleconferences in order to build better leaders, who would wisely take care of their team members.

\section{(2) Transparency in the M\&A Process}

Generally speaking, in a company with a strong labor union, the information on the M\&A process is kept strictly confidential and only the surface results of the negotiations are announced to the employees. However, such confidentiality makes the employees amplify suspicion or skepticism, which drives the labor union to rise up with stronger rejection due to the fear of losing their jobs. Since 2009 , the management has made all the information on the M\&A available to the employees, including the management's effort in securing the succession of employment, CBA and the benefits, and the working conditions. By showing more transparency to its employees, the management has entitled the employees with the sense of belonging to the company. Such a move has also helped build trust among the employees towards the management after the KKR buyout.

\section{(3) Active Use of Communication Channels: Open Consultation Room, Regular}

One-on-one Meetings

To encourage employees to communicate more frequently and freely with the management, each team manager and employees have one-on-one meeting every month. In 2008, the company has also opened an online board on its groupware, where employees can post hardships, complaints, and requests anonymously. 
Anonymity is secured, and the management responds to the feedback as quick as possible. The primary response to the feedback is sent within 24 hours, and any additional information is provided within 48 hours. Not to mention, any employyees, irrespective of the job title, can communicate using the Q\&A board to share useful knowledge and ideas.

\section{The Second-step Strategies with a View to Growth by Utilizing the Stabilized} Industrial Relations

(1) Adoption of the Job-Grade System and "Incentive by Performance" System: the Base for Meritocracy

The job-grade system is that the company lists all job positions with an order of relative value, and anyone in the same position receives the same salary regardless of age or the number of years spent at the company. The system sets an annual salary in advance, based on the value of the works or the individual's performance. OBC has adopted such system in 2001, after consulting with the labor unions. At the time, many of the local companies have been adopting the performance-based annual salary system, but rarely the job-grade based salary system. Although the labor unions have opposed at first, they have agreed to adopt the job-grade based system to rebuild the growth momentum for the company. This was a difficult call for the labor unions, signifying a great milestone for securing a competitive edge for the further growth of the company. The competitor Hite-Jinro currently, operates the stepped-up salary system (service year-based step salary system) as of 2012 for the all employees. Considering that many other companies have experienced numerous disputes including strikes with the attempt to change their traditional stepped salary system to the newer one, the early adoption of the job-grade based salary system at $\mathrm{OBC}$ has helped the company gain growth momentum.

The management and the unions have finally reached an agreement due to the management's continuous effort to persuade the employees, and this caused an eventual paradigm shift. Also, the company has adopted a meritocratic incentive program to further boost teamwork among divisions (production, sales, and headquarters). With such salary and incentive system, the company has opened up doors to support meritocracy.

After the company was bought out by KKR, the salary and incentive system survived and been was improved with its main framework and spirit maintained. The incentive system basically comprises three factors - the size of pie (EBITDAEarnings before interest, tax, depreciation, and amortization), the entity target, and the team target. And total incentive was the sum of the three factors. i.e. Size of 
pie (EBITDA) score plus Entity target score plus Team target score. In 2011, the company started applying the individual KPIs to the incentive program as well to enhance the meritocracy spirit. The incentive calculation method changed to the multiple of three factors from the former sum of three factors. i.e. Size of pie (EBITDA) score $(\max 110 \%)$ times Entity target score $(\max 100 \%)$ times individual KPI score(max 100\%). Since 2012 EBIT (Earnings before Interest and Tax) of each plant has become the common factor for all plant employees. And the sales force people have been applied to the variable monthly sales incentive.

Such a move has brought strong motivation to its employees to perform better, and added fairness when paying the extra compensation. As EBITDA has become the common factor, each team has become more cooperative with one another to achieve the targets. If one team falls behind, it may become almost impossible for all employees to meet the EBITDA target. The incentive programs based on meritocracy have become active as they were agreed upon by the unions. The main reason that the unions agreed to such aggressive incentive system was the consensus that growth and increased competitiveness of the company would provide better job security under the ownership of private equity fund, which would eventually sell OBC to another investor. Also, the management maintained the fairness and rationality in target setting since this incentive system not only provides a very aggressive compensation when the targets are met but also painsharing when not. When the performance achievement exceeds the previously set goals, the management awards much more incentives. However, anyone who has not reached at least 90 percent of the goals does not get a penny. (e.g. EBITDA score $(=$ zero $) \times$ Entity target score $\mathrm{x}$ KPI score $=$ ZERO). The effective incentive system and the pain-sharing mechanism led the company to more growth.

FiguRE 1. THE INCENTIVE SYSTEM OF OBC

\begin{tabular}{|c|c|c|c|c|c|}
\hline \multicolumn{8}{|c|}{ Incentive Scheme } \\
\hline \multirow{2}{*}{$*$ SOP } & $\mathrm{x}$ & \multicolumn{2}{|c|}{ Entity target achievement (100\%) } & & $\begin{array}{c}\text { Individual KPI } \\
\text { achievement } \\
(100 \%)\end{array}$ \\
\cline { 3 - 4 } & & $\begin{array}{c}\text { Company } \\
(70 \%)\end{array}$ & $\begin{array}{c}\text { Each team } \\
\text { or division } \\
(30 \%)\end{array}$ & $\mathrm{x}$ & \\
\hline
\end{tabular}

SOP (Size of Pie) is determined based on EBITDA (Earnings Before Interest, Tax, Depreciation and Amortization) target achievement rate.

KPIs: Key Performance Indicators.

\begin{tabular}{|c|c|c|c|c|}
\hline $\begin{array}{c}\text { EBITDA target } \\
\text { achievement rate }\end{array}$ & $90 \%$ & $100 \%$ & $105 \%$ & $110 \%$ \\
\hline SOP & $0 \%$ & $110 \%$ & $120 \%$ & $125 \%$ \\
\hline
\end{tabular}

SOP: size of pie, for example, anyone achieves 105 percent of the original goal will receive extra 20 percent of its annual salary( $120 \%$ as SOP in the formula) as incentives if the she achieved $100 \%$ of entity target and $100 \%$ of individual KPIs.

SOURCE: Oriental Brewery. 


\section{(2) 2 E Project: Increase in the Employee Engagement/Satisfaction Level}

OBC's new salary system based on individuals' performance has helped the employee to compete and to cooperate at the same time. The company has become more competitive in the market since 2008. Hence, it has been possible for the company to encourage the employees to achieve more by rewarding them with the extra profits earned in line with the transparent management system.

In 2008, the management revised the system, which had not been modified since 2001. First, the management has introduced more a competitive culture among the employees by complementing the existing job-grade system with the competence level evaluation. Second, to foster more talented labor force, the company put more efforts in internal training, and facilitating the inter-department promotion and relocation. Third, the management offered more rewards and opportunities to talented employees. Fourth, to spread healthy, yet competitive culture within the company, the management emphasized the five competences (stretching the target setting, leading with best examples, achieving the target with the company's methods, thinking and acting with ownership, and finally raising talents and best teams) and the ten principles (corporate culture under "Drive, People and Culture"). Labor and management both put a great amount of effort to form a consensus on taking the new system, in an attempt to encourage the company to grow competitiveness in the market. This move is regarded as one of the major drivers that has made $\mathrm{OBC}$ to lead the market.

\section{(3) The Sales Incentive Program: the Upgrade}

The management changed its sales incentive programs in 2009, which previously had been paid based on the yearly performances. Sales staff was evaluated for a monthly incentive payment. On top of their base fixed salary that represents $80 \%$ of average annual salary, each staff was able to receive an additional incentive up to $40 \%$ of the previous annual salary based on performance in the previous month. The management has adopted this "Sales Variable Payment" system in order to motivate the sales force into better performance for immediate rewards.

Such system can be burdensome for certain employees, due to the demanding nature. However, the union agreed to adopt the new system after a series of long discussions with the management, understanding that it was a measure to make the company grow further. The labor has put efficiency up front and has accepted the fact that individuals may show different levels of performances. Such system has never been considered an option for $\mathrm{OBC}$, with the existence of the strong labor unions. Yet, the decision was made as the unions agreed to put the top priority to the company's growth. Then the employees fought to win their shares of rewards based on their performances. 


\section{(4) Each Plant Accountable for its Own Profit and Loss}

Before 2010, plant employees had nothing to do with the top line numbers. The employees had KPI targets mostly related to productivity, such as variable industrial cost, variable logistics costs, utility cost per unit, etc. However, after 2010, the company adopted a new system, which holds each plant accountable for its own profit and loss. Plants are also responsible for preventing any business interruption, such as major product quality problems or strikes. Before then, plants had focused just on finding ways to cut production cost.

\section{(5) Two Targets at the Same Time: More Growth and More Employee Satisfaction}

In 2008, the company set a goal for itself to score at least $80 \%$ for EOS (Employee Opinion Survey) by listening to the difficulties that the employees were facing while working harder for the further growth of the company, and by providing better welfare programs and compensation.

The company has managed to raise the EOS level every year. With its performance-based system that provides higher incentives than any other companies in the same industry, the company finally had the employees satisfied with the compensation and working conditions. The company started to provide financial support for the medical treatments of employees and their family members, as well as for private health insurance to give workers a sense of security. It established an overseas travel program for 200 employees each year, and it adopted a "cafeteriatype" welfare system in an attempt to keep the employees more satisfied.

\section{(6) Corporate Culture}

OBC has set its core value - Process, Recognition, Informality, Drive, and Ethics (PRIDE) - which had become the slogan for the company to raise its selfconfidence. The management had been promoting those values in all company occasions, in order to install more "open" culture. Even all employees were strongly suggested to call each other by English nicknames without referring to the job title, whilst keeping the proper work decorum. The management also encouraged its employees to recognize one another for good performances, by awarding anyone who sets an exemplary model every month at an event called "Recognition Nite." The company also encouraged the workers to wear casual attire in the office. Partitions and screens in the offices were removed so that employees could communicate easier with one another. The "PRIDE" culture has been mentioned in many local media reports and appears to be a contributing factor to OBC's growth. The leaders at the labor union also used English nicknames so that the slogan of the company could be settled in the early stage. 


\section{CONCLUSION AND MANAGERIAL IMPLICATIONS}

OBC was selected due to its unique features; First, OBC was formed through three times of M\&As, the most recent one of which was by KKR, a private equity fund in 2009. Second, due to this M\&A legacy, OBC has had dual unions since 1999 before it was legalized in 2011. Third, most of all, its performance is incomeparable to any Korean large companies for the last 5 years. The market share grew at least $15 \%$ p. during the recent 5 years. Therefore, OBC should be an exemplary candidate for analyzing the mixed impact and dynamics of M\&As, their cultural implications, and the union-management relations in light of the business performance.

Since the management set up a mid-term plan with a view to mitigating the union risk in 2007, OBC, with the not-so-friendly dual unions, has been achieving a remarkable performance in changing the labor union risk into the contribution factor to financial and operational performances.

In summary, recognizing the union as the management partner, implementing consistent and fair performance-based compensation system, and building up the employees' trust through open communication appear to be the key contributing factors to OBC's success.

Under the prevalent negative perception of the Korean people and the labor unions with a deep-rooted suspicion of "dine-and-dash!(eat-and-run in the local terms)" on the foreign invested companies, it appears warranting the attention of not only the potential foreign investors who are hesitating due to the union risk in Korea, but also the policy makers who try to attract foreign direct investment for continuing economic growth. This OBC case should provide them with very strong implications and insights towards a roadmap to success despite the inherent weakness contained in the case study in terms of generalization.

The managerial implications for the foreign-invested enterprises in the context of stabilizing the industrial relations are (1) to build up a partnership with the labor union, (2) to have human resource management focusing on raising productivity, (3) to take problem-solving strategies that center around the labor force on-site, (4) to set up and stick to the principle-based rules regarding the industrial relations, and (5) to have a built-in ex-ante discussion process to avoid excessively heated labor disputes.

\section{FUTURE RESEARCH}

There are three areas to be considered for further research: (1) the quantification of a negative impact caused by the hostile union risk on the enterprise value, (2) the combination of this idiographic case and generalization of implications from this case with further case studies in the context of foreign direct 
investment including M\&A, and (3) the combination of the operational perspective and the human resource management perspective with more concentration on the union management relations as a subset.

\section{REFERENCES}

Bamber, Greg J. and Russell D Lansbury, 2000. International and Comparative Employment Relations $3^{\text {rd }}$ Ed.

Cartwright, Susan, and Cary L. Cooper. 1993. The role of culture compatibility in successful organizational marriage. Academy of Management Executive 7(2).

Cartwright, Susan, and Richard Schoenberg. 2006. Thirty Years of Mergers and Acquisitions Research: Recent Advances and Future Opportunities. British Journal of Management 17: S1-S5.

Cho, Sung-Jae. 2004. An Analysis of Determining Factors of Labor Strike in Korea, Korea Labor Institute: 44-45,

Kavanagh, Marie H., and Neal M. Ashkanasy. 2006. The Impact of Leadership and Change Management Strategy on Organizational Culture and Individual Acceptance of Change during a Merger. British Journal of Management 17: S81-S103.

Kim, Tae-gi, and Bong-jun Yoon. 1991. Studies on labor disputes. Korea Labor Institute : 71-79.

Labor ministry's industrial relations cooperation policy division. 2008. Yes Korea! Reports on successful establishment of industrial relations at Korea's foreigninvested enterprises in 2008. Ministry of Employment and Labor.

Labor ministry's industrial relations countermeasure team. 2008. Analysis of labor disputes and related statistic. Ministry of Employment and Labor.

Larsson, Rikard, and Sydney Finkelstein. 1999. Integrating Strategic, Organizational, and Human Resource Perspectives on Mergers and Acquisitions: A Case Survey of Synergy Realization. Organization Science 10(1).

Nahavandi, Afsaneh, and Ali R. Malekzadeh. 1988. Acculturation in Mergers and Acquisitions. Reviewed work(s). The Academy of Management Review 13 (1): 79-90.

Noh, Yong-Jin and Kim Dong-Woo. 2003. A Study on the Labor-Management Rela-tions of Foreign Invested Companies, Korea Labor Institute: 33-36.

Riad, Sally. 2005. The Power of 'Organizational Culture' as a Discursive Formation in Merger Integration. Organization Studies 26(10): 1529-1554.

Schraeder, Mike. and Dennis R. Self. 2003. Enhancing the success of mergers and acquisitions: an organizational culture perspective. Management Decision 41 (5): 511-522.

Sheridan, John E. 1992. Organizational Culture and Employee Retention, Reviewed work(s). The Academy of Management Journal 35(5): 1036-1056. 
Shin, Soo-Shik, Dong-Won Kim, and Gyu-Yong Lee. 2012. A Study on Modern Employment Relations (Development of Labor Movement and Employment Relations of Various Countries): Chapter 2, Parkyoungsa.

Weber, Yaakov, Oded Shenkar, and Adi Raveh. 1996. National and Corporate Cultural Fit in Mergers/Acquisitions: An Exploratory Study. Reviewed work(s). Management Science 42(8): 1215-1227. 


\section{ENDNOTES}

1 KKR and Co. L.P. (formerly known as Kohlberg Kravis Roberts and Co.) is an American multinational private equity firm, specializing in leveraged buyouts, headquartered in New York. The firm sponsors and manages private equity investment funds. Since its inception, the firm has completed over $\$ 400$ billion of private equity transactions and was a pioneer in the leveraged buyout industry. The firm was founded in 1976 by Jerome Kohlberg, Jr., and cousins Henry Kravis and George R. Roberts, all of whom had previously worked together at Bear Stearns, where they completed some of the earliest leveraged buyout transactions. Since its founding, KKR has completed a number of landmark transactions including the 1989 leveraged buyout of RJR Nabisco, which was the largest buyout in history to that point, as well as the 2007 buyout of TXU, which is currently the largest buyout completed to date. KKR has completed investments in over 160 companies since 1977, completing at least one investment in every year except in 1982 and in 1990.KKR is headquartered in New York City with 13 additional offices in the United States, Europe and Asia. In October 2009, KKR listed shares in the company, through KKR and Co. an affiliate that holds $30 \%$ of the firm's ownership equity, with the remainder held by the firm's partners. In March 2010, KKR filed to list its shares on the New York Stock Exchange (NYSE), with trading commencing four months later, on July 15, 2010 (Source: Wikipedia).

2 Affinity Equity Partners is one of the largest dedicated Asian private equity firms and focuses on leveraged buyout and growth capital transactions. Affinity operates as a Pan-Asian firm focusing on investment opportunities in Korea, Australia and New Zealand, Greater China and Southeast Asia. The firm is led by Kok-Yew Tang (Chairman and Managing Partner) and Young-Taeg Park (Managing Partner). It has over 50 employees with offices in Hong Kong, Singapore, Seoul, South Korea, Sydney, Australia, Jakarta, Indonesia and Beijing, China. Among Affinity's investments in Korea are the following: Kyobo Life Insurance, Pulmuone Foods, Oriental Brewery, Korea Digital Satellite Broadcasting, TheFaceShop, Himart, Haitai Confectionery, Mando Corporation, WiniaMando, MK Electron, LOEN Entertainment (Source: Wikipedia). 